\title{
Exploring mindful consumption, ego involvement, and social norms influencing second-hand clothing purchase
}

\author{
Nawaz Muhammad Zahid · Jashim Khan ${ }^{2}$ (D) Meng Tao ${ }^{1}$
}

Accepted: 21 December 2021

(c) The Author(s) 2022

\begin{abstract}
Second-hand clothing (SHC) benefits society by reducing the wastage of natural resources. Research in the purchase of second-hand clothing is a debated topic. It is not yet clear whether caring for self, community, and nature drives the purchase of second-hand clothing. This study unpacks the intervening factors that drive second-hand clothing purchases underpinning attitude-intention and self-determination theories. The primary purpose is to examine the direct relationship between a) mindful consumption, b) ego-involvement, c) social norms on second-hand clothing purchase intention of young consumers. The mediation of ego-involvement and social norm is examined on the above relationship. A total of 314 usable questionnaires following the convenience and purposive snowball sampling techniques were gathered from China. The structural equation model (SEM) two-step approach analyzed the data. SmartPLS3 statistical package used to run the measurement and structural model analyses. IPMA analysis confirms mindful consumption as an important factor; hence ego-involvement drives the performance of the stated relationship. Ego-involvement mediates the relationship between mindful consumption and second-hand clothing purchase. This study bridges the unanswered questions and highlights the importance of mindful consumption, an essential driver of consumer behavior. Managers are encouraged to promote mindful consumption values in marketing communication to drive sustainability.
\end{abstract}

Keywords Second-hand clothing $\cdot$ Mindful consumption $\cdot$ Social norms $\cdot$ Ego-involvement

\section{Introduction}

Disposing second-hand clothes (SHC) is a massive waste of resources that harms the environment, creates landfill problems, and contributes to deforestation. At the same time, textiles' manufacturing is detrimental to the environment for its toxic waste, similarly to the disposal of SHC (Bjurbäck, 2015). The reuse of SHC underpins mindful thinking - a customer-centric approach to sustainability (Mohammad et al., 2020; Sheth et al., 2011), mainly in Western countries. Western consumers find mindfulness thrilling as it compounds caring for self, community, and natural environment,

Jashim Khan

j.a.khan@surrey.ac.uk

Meng Tao

mengtao@dufe.edu.cn

1 Dongbei University of Finance \& Economics, 217 Jianshan St, Shahekou 116025, China

2 University of Surrey, Guildford GU2 7XH, Surrey, UK coupled with economic benefits (Weil, 1999). One's concern for self and the environment is rooted in studies on the used clothes (Watson et al., 2016) and psychological benefits (Lang \& Zhang, 2019). Perceived economic benefit, environmental concern, and subjective norms are the influential factors influencing the purchase intentions of SHC (Roux \& Guiot, 2008). The financial benefit caters to one's self-interest, whereas environmental concern is motivated to sustain the community and nature (Liu \& Valente, 2018). The role of economic, environmental, and hedonic value is known to influence buying SHC (Xu et al., 2014). Second-hand clothing market (e.g., redistribution systems) falls under collaborative consumption (Becker-Leifhold \& Iran, 2018; Botsman \& Rogers, 2010, 2011; Iran \& Schrader, 2017) involving markets, where strangers, as opposed to kin and acquaintances, exchange goods and services (Schor \& Fitzmaurice, 2015). Within collaborative consumption, researchers have yet to understand how the intrinsic motivational factors that influence consumers towards caring for self, environmental concern, or uniqueness influence the purchase of SHC (Luo et al., 2020). 
Consumption is related to thoughtful thinking (Arslan \& As1c1, 2021), determined by the mindset of individuals governing mindful behavior (Gao et al., 2021). Mindfulness incorporates attitudes, values, and expectations surrounding consumption behavior (Peterson \& Simkins, 2019). The fact that people care about themselves, the people around them or significant others, and the natural environment, posit economic, social, and natural environmental sustainability (Sheth et al., 2011). Mindful thinking corresponds to reducing harm to oneself, significant other, and the environment. Antonetti and Maklan (2014) suggest that self-conscious emotions (e.g., shame, guilt, and pride) that require selfreflection may influence mindful thinking (Bennett et al., 2017; Hwang \& Lee, 2019). Baer et al. (2006) reported that mindful thought might interact with self-conscious emotions that intrigue people to believe that their decisions can significantly affect environmental and social issues and are more likely to behave sustainably. De Charms (1968) labeled this phenomenon as ego-involvement (a condition in which there is a menace to self-esteem). Ryan and Deci (2017) claim that guilt and pride operate as a process that is called introjection (unconscious process wherein one perceives from other's identity, notably significant others, such as feelings, experiences, and cognitions) (Hinshelwood, 1995). The introjected regulation is characterized by ego-involvement (Ryan, 1982) because the goal is to gain and maintain approval from the self and significant others, labeled as the social norm (Ajzen, 1991). Several studies have considered introjection and egoinvolvement (Howard et al., 2021; Jakobsen, 2021) and selfdetermination theory (Goldfarb et al., 2021) to study mindful consumption. The ego-involvement comportment is stimulated by a yearning to guard and augment self-esteem; hence, guilt and pride seem to operate as the intrinsic motivator to sustainability, emulating intentions for SHC purchases. Tangney and Fischer (1995) suggest guilt and pride, a selfconscious emotion, influence one's self-esteem.

Ego-involvement is an ongoing concern for a tangible or intangible product or idea (Carpenter, 2019). Consumers with a deep respect for the natural environment and economic and social well-being may display ego-involvement shaping their SHC purchase intentions. The second assumption is that pride may interplay with ego-involvement as the underlying driver of sustainable behavior as the individual may feel good while displaying or talking about SHC purchases within the social community. In general terms, people dislike the consumption of clothes used by others (Cervellon et al., 2012). However, Xu et al. (2014) hypothesized that young consumers had little experience buying SHC, primarily due to readily available low-priced new clothing in China. Young Chinese consumers' who intend to purchase SHC may have various motives such as economic/environmental benefit or be driven by mindfulness influencing egoinvolvement susceptibility to subjective norms (Xu et al.,
2014). This research investigates whether Mindfulness, ego involvement, and social norm matter to young consumers in China - intending to purchase second-hand clothing emulating a customer-centric approach to sustainability.

The following section provides a literature review of the fundamental concept, drawing the relationship between mindfulness and self-conscious emotions weaving egoinvolvement to self-determination theory following the role of social norm influencing SHC purchasing intention.

\section{Mindfulness}

Mindfulness - an idea originating from the Buddhist belief system (Chu et al., 2018) -focused on society's needs, welfare, and well-being (Sangharakshita, 2003). Other sources suggest mindfulness has its root in old Greek philosophy, western European thought, and the humanism of old native America (Brown et al., 2007). One common standard is 'attention and awareness' (Hakan et al., 2017). Mindfulness creates and strengthens the positive feelings in human beings and increases the emotions of carefulness, empathy, and warmth for ourselves, others, and the environment (Johnson et al., 2009). Mindful people are actively engaged in the present, are sensitive to context, and display feelings of affection and kindness for themselves and others (Dhandra, 2019).

In their study, Milne et al. (2020) noted that mindfulness is associated with self-regulation driven by self-conscious emotions such as guilt and pride, which determines sustainable behavior, enlarging self-esteem. Mindfulness influences self-control by deliberately regulating self-conscious emotions that may enhance their self-esteem and pride and minimize guilt for the good of themselves and others related to environmental and sustainable behavior (Friese et al., 2012). Studies in cognitive processing suggest that some intended behaviors follow automatic thought that does not require awareness or intention (Brown et al., 2013; Hakan et al., 2017). Peterson and Pbert (1992) elaborate that selfconscious emotions influence people's thought processes and that behavior related to enhancing one's ego and pride or reducing guilt are deliberately regulated, displaying enhanced self-control. Mindfulness involving self, others, and society is likely to enter the conscious awareness and attention and be taken as a priority governing sustainable behavior (Frewen et al., 2008). Hakan et al. (2017) explained that mindfulness converts automatic judgments to mindful judgments regulated by self-conscious emotions (such as pride, ego, and guilt) (Grossman, 2010; Hakan et al., 2017). The deliberate behavior results from self-regulation influenced by conscious thoughts and feelings vary from situation to situation. Michaelidou and Dibb's (2008) study directs that people attach more weight to those situations that correspond to their values and interests. Mindfulness's central 
tenet, 'awareness' and 'attention,' regulate self-conscious emotions that people may put more weight on problems that enhance their self-esteem within the social community. People who are aware of themselves and their social and environmental surroundings are more likely to engage in mindful thinking and take pride in displaying sustainable behviour.

Researchers found the connections between mindfulness and social sustainability (Sajjad \& Shahbaz, 2020). Several authors advocate that mindfulness might be associated with improved sustainable behavior because it fosters empathy, compassion, and altruism (Ericson et al., 2014; Fischer et al., 2017). Research in the effect of mindfulness on sustainable behavior is in infancy and requires further research (Donald et al., 2019; Luberto et al., 2018).

\section{Ego-Involvement}

Ego-involvement is a versatile construct, employed in different perspectives and theories since its instigation (Carpenter, 2019). The construct utilized to assess intrinsic and extrinsic goals motivations with self-determination theory (Vansteenkiste et al., 2007a7, b); to evaluate partisan bias with social judgment theory (Bergan, 2021), and to assess users intentions with the idea of planned behavior (Park et al., 2015). The literature presented the construct with different definitions from different perspectives. In this research, the focus is on the earliest definition, "ego-involving attitudes are those, that have been learned, largely as social values; that the individual identifies himself with, and makes a part of himself; and that have affective properties of varying degrees of intensity" (Carpenter, 2019; Sherif \& Cantril, 1947). Research suggests that self-conscious emotions such as enhancing pride and minimizing guilt are associated with ego-involvement (Carpenter, 2019). Sherif and Hovland (1961) argue that individuals appraise contents of personal relevance that enhance the individual's worth in the social community. Personal relevance influences attitude formation, values, and self-identity; these qualities are associated with the individual's ego involvement construct. Ego involvement is viewed as 'the extent to which individuals' self-concept is connected with their position on a particular issue and forms an integral part of how individuals define themselves" (Lapinski \& Rimal, 2005), it is a part of selfidentification (Eagly \& Chaiken, 1993) and self-image (Perloff, 1989).

Literature on motivated reasoning (make decisions that are most desired rather than those that are accurate) (Molden et al., 2021; Petty et al., 1992) and cognitive dissonance (Carpenter \& Cruz, 2021) make a compelling case for studying ego-involvement in relationship to SHC purchase intention. When ego involvement contradicts one's attitude, value, or identity will produce cognitive dissonance and thus spur motivated reasoning to reduce guilt, and conversely, when ego involvement is supported will enhance pride (Bergan, 2021). Dixit et al. (2019) support the notion that selfconscious emotions are likely to influence ego involvement and behavior and significantly predict consumer intention (Park et al., 2015). Further literature states that ego-involvement connects an individual's core values and willingness to commit to a given behavior (Dixit et al., 2019; Park et al., 2011). When individuals respond to their ego-involvement to maximize pride or minimize their guilt of failing to maintain the ego-involvement in the social gathering, they are essentially responding to self-regulation-the support for this type of self-regulation requires adequate awareness and attention, an essential quality of mindfulness. Self-determination theory (Ryan \& Deci, 2000) supports individuals' self-determination to uphold their identity, image, and values within the social group (Deci \& Ryan, 2012; Vansteenkiste et al., 2007a, b).

Two different behavioral regulations: self-directed and controlled regulation, governs self-determination theory. Individuals perform specific behavior based on their choice, which is influenced by serving internal or external demand. The self-directed regulations demand awareness and attention to one particular personal cause or relevance of the situation that motivates to perform a specific behavior. Selfregulation involves mindful thinking to achieve a goal of mindful behavior. The theory upholds different goals produces varied outcome behavior (Deci \& Ryan, 2000; Vansteenkiste et al., 2007a, b). The former self-directed regulation satisfies the intrinsic goal to regulate self-conscious emotions and thoughts, and mindfulness likely influences the thought process. The second goal to satisfy extrinsic motivation reflects people's desire to impress others (Kasser \& Ryan, 1996; Williams et al., 2000). Howard et al. (2021) suggested a critical intrinsically driven yet extrinsically goal is introjected regulation, which represents a state driven by internal dynamics related to self-esteem, such as guilt/shame avoidance and pride seeking (Howard et al., 2021; Ryan \& Deci, 2017). Introjected regulation is characterized by egoinvolvement (Ryan, 1982) because the goal is to gain and maintain approval from the self and others. External regulation is the psychological state enacted when individuals seek out externally controlled rewards or avoid externally administered punishments (Howard et al., 2021).

With this understanding, this research examines the ego involvement of second-hand clothing purchase intention. Consumers who have a deep concern for themselves, others, and the natural environment may display ego-involvement. Those likely participate in activities that exhibit mindfulness and harness social norms among peers. An example of egoinvolvement and self-conscious emotion is demonstrated in the study by Park et al. (2011), drawing intrinsic and extrinsic motives to contribute to Wikipedia with no immediate financial profit or personal gain. 


\section{Social Norms}

Fishbein and Ajzen (1975) proposed the theory of reasoned action, suggesting that consumers' intention is governed by their personal beliefs and the subjective norm (Xu et al., 2014). Subjective norms are operationalized as the peer pressure within a social circle to act according to group expectations, including family, friends, partners, and colleagues. Social norms are a sub-construct of reasoned action theory with multiple applications in various business contexts, such as voluntary behavior (Kim et al., 2011). According to the idea of reasoned action (Fishbein \& Ajzen, 1975), attitudes that influence behavioral intention are also shaped by subjective norms. Social influences posit that social relations create strong word-of-mouth about the specific behavior that eventually makes strong behavioral intentions (Sohn, 2010). Subjective norms are an individual's perception of the social pressure, and that Dixit et al. (2019), in the context of the online review, suggest that intention to write an online review may have been to impress significant others. Thus, acting sustainably by showing positive intention to SHC may be influenced by ego-involvement and mindfulness.

\section{Conceptual Development}

\section{Mindfulness \& SHC Buying Intention}

Mindfulness asks for self-awareness and attention influencing mindful thinking results from self-regulation of self-conscious emotions, where individuals choose between sustainable outcomes (Milne et al., 2020) that may maximize their social standing and minimize the guilt of not doing the right thing. Within the context of sustainable green consumption, Jin et al. (2020) suggest that acting with awareness and attention to self, social and environmental well-being are correlated (Jacob et al., 2009). (Geiger et al., 2018) support the linkage between conscious consumption and sustainable clothing consumption. The relationship between mindfulness and sustainable buying intentions influenced by social consciousness is supported (Dhandra, 2019). Recent studies have suggested that mindfulness relates positively to sustainable behaviors (Jin et al., 2020; Milne et al., 2020); SHC purchase intention is an example of mindfulness in this study (Barbaro \& Pickett, 2016). Therefore, we propose:

Hypothesis $1\left(H_{1}\right)$ : Mindfulness will have a positive impact on buying intentions of second-hand clothing.

\section{Mindfulness \& Ego-Involvement}

Goleman and Davidson (2017) confirm that mindfulness is essential, rendering individuals more prosocial and ethical.
Mindfulness facilitates the regulation of thoughts and emotions beneficial to self, others, and the environment (Schuman-Olivier et al., 2020). Deci and Ryan (1991) proposed introjection as a mechanism to explain that social connectedness is a motivation to gain and maintain social approval from the self and significant others. Ego-involvement holds that self-conscious emotions, such as pride and guilt, are relevant to one's belief system, manifest a motivation to attain the goal that enhances ones' ego involvement (Lai \& Chen, 2011; Michaelidou \& Dibb, 2008). Ego-involvement relates positively to achieving self-identity, self-esteem, empathy, and vision (Abbasi \& Akhlaghi-fard, 2021). People with mindfulness traits experience less ego depletion (Abbasi \& Akhlaghi-fard, 2021; Lykins, 2009).

Mindfulness supports social connectedness. Research reports that mindful people are more likely to regulate their self-conscious emotions such as guilt and pride that influence their self-esteem (Deci \& Ryan, 1991). Mindfulness can contribute to self-esteem by promoting the authenticity of self-regulation and acceptance of social pressure within a social group (Carson \& Langer, 2006; Dekeyser et al., 2008). Recent studies have suggested that mindfulness relates positively to sustainable behaviors (Barbaro \& Pickett, 2016). The literature also supports the relationship between mindfulness and ego involvement (Heppner et al., 2008). The greater insight into self and concern for others and environment emancipate from ego involvement (Beitel et al., 2005; Brown et al., 2007). Therefore, we propose:

Hypothesis $2\left(\mathrm{H}_{2}\right)$ : Mindfulness will positively impact ego-involvement in the context of buying second-hand clothing.

\section{Ego-Involvement \& Buying Intention}

Individuals feel that a specific behavior's performance is essential and pertinent based on how the benefit outweighs the cost of the action (Lai \& Chen, 2011). Perloff (1989) argue that ego-involvement influence self-esteem, while Sherif et al. (1965) viewed ego-involvement as being connected to how others perceive the individual within the social community (Park et al., 2012). With this understanding, this research examines the ego-involvement of young Chinese consumers association between their buying intention of SHC. The vigorous promise to the word of mouth of the buying intention within the social community may strengthen the pride of individuals and position as a carer of environment and sustainability. On the other hand, noncompliance with ego-involvement may create guilt feelings (Čater \& Čater, 2010; Cater \& Zabkar, 2009). People who have a deep concern for the natural environment may display ego-involvement, shaping SHC purchase intention. Some studies demonstrate a relationship between ego-involvement 
and intention-behavior linkage (Chang \& Chuang, 2011; Yu et al., 2010). In line with this reasoning, this study proposes that:

Hypothesis $3\left(H_{3}\right)$ : Ego-involvement has a positive impact on buying intentions of second-hand clothing.

\section{Ego-Involvement \& Social Norms}

Extant research suggests a clear linkage between egoinvolvement seems to be influenced by self-conscious emotions such as pride and guilt that regulate individual behavior and impact their self-esteem (Cater \& Zabkar, 2009). Self-esteem heightens the inner satisfaction of taking pride in one's thoughts and feeling (due to intrinsic motivation). It may result in extrinsic motivation displaying behavior towards good for themselves, society, and the environment. When people communicate their intention to purchase second-hand clothing within their social circle or gain the approval of significant others, it influences self-esteem (McDermott \& Lachlan, 2020; Siero \& Doosje, 1993). Similarly, when a social norm within a social circle upholds sustainability, in this instance, buying intention of SHC, the feeling of obligation can cause guilt if not performed (Čater \& Čater, 2010).

In their work on ego-involvement, Sherif and Sherif (1967) noted that group membership affects latitudes of acceptance and rejection of group norms that potentially heighten group members' self-conscious emotions (McDermott \& Lachlan, 2020). Elliot (2005) argues that egoinvolvement within a social circle entails impressing others (e.g., peers, parents, and friends) by demonstrating superior skills or knowledge (Rawsthorne \& Elliot, 1999). Therefore, ego-involved individuals are focused on proving their abilities, receiving favorable assessments of their competence, and defending their ego and self-esteem (Deci, 1985; Ryan, 1982), thus influencing their social circle. Therefore, we propose:

Hypothesis $4\left(H_{4}\right)$ : Ego-involvement positively impacts social norms in the context of buying second-hand clothing.

\section{Social Norms \& Buying Intention}

Although the consumers' interests and attitudes relate positively, intentions are not always consistent with the specific attitudes. Studies show mixed social norms and buying intent (Jung et al., 2020). Liang and Xu (2018) confirmed the relationship between the consumer intention to buy SHC and social norms and indicated Chinese consumers strongly resist SHC as they can access low-priced new apparel (Khan $\&$ Rundle-Thiele, 2019). Similarly, Borusiak et al. (2020) and Varshneya et al. (2017) found that social norms are negatively related to buying intention of organic clothing. (Okur \& Saricam, 2019) argue that compliance with social norms posits faster diffusion of sustainable clothing. In line with this reasoning and the literature's augments, the current study proposed that positive social norms will create positive intentions to buy second-hand clothing.

Hypothesis $5\left(H_{5}\right)$ : Social norms have a positive impact on buying intentions of second-hand clothing.

\section{Mindfulness, Ego-Involvement \& Buying Intention}

Mindful thinking influences behavior by regulating selfconscious needs, values, feelings, and situational demands (Leary et al., 2006). The self-regulatory mechanism focuses on oneself, society, and the environment (Beitel et al., 2005). Lykins (2009) suggests that people with mindfulness experience less ego depletion or choices related to their actions, which minimizes the feeling of guilt. Mindful individuals pay superior attention while making buying decisions by carefully buying to prevent harmful consequences on self, community, and nature (Dhandra, 2019). Abbasi and Akhlaghi-fard (2021) found that mindfulness is related to intentions to purchase green products, and Dhandra (2019) study supported ecological behavior. Geiger et al. (2018) endorsed the linkage between conscious consumption and sustainable clothing consumption. Researches in this domain support that mindfulness and purchase intention may have a relationship. At the same time, the literature supports the relationship between mindfulness and ego involvement (Heppner et al., 2008). Based on Ryan's (1982) introjection, several studies considered ego-involvement influenced by self-conscious emotions (Howard et al., 2021; Jakobsen, 2021). This research suggests that ego-involvement can potentially affect the relationship between mindfulness and intention to purchase second-hand clothing.

Hypothesis 6aa $\left(H_{6 a}\right)$ : Ego-involvement mediates the relationship between mindfulness and buying intention of second-hand clothing.

\section{Ego-Involvement, Social Norms \& Intention}

Baer et al. (2006) reported ego-involvement interacts with self-conscious emotions that intrigue people to believe that their decisions can significantly affect environmental and social issues and are more likely to behave sustainably. Literature of empirical studies showed the association between ego involvement and attitude/intention (Johnson \& Eagly, 1989; Park et al., 2011, 2015), and the association between ego involvement and perceived behavioral control (Park \& Yang, 2012), and the relationship between ego involvement 
and purchase behavior (Knight Lapinski \& Boster, 2001). The consumer with high ego-involvement with buying SHC will try to control their family and peers and significant others to perform the same behavior to satisfy their self-esteem. When a social norm is upheld within a community, the members are expected to share the same values that reflect consistent behavior. With this reasoning, we propose that:

Hypothesis $\boldsymbol{6} \boldsymbol{b}\left(H_{6 b}\right)$ : Social norms will positively mediate the relationship between ego-involvement and buying intention of second-hand clothing.

\section{Methodology}

\section{Research Context}

One of the reasons for air pollution and industrial water pollution in China is the textile industry's rapid development (Zhang et al., 2010). About 65\% of the total world's clothing production is produced in China, and around $90 \%$ of them are made of blended fabric, so burning or dumping will release toxic material, causing more pollution in the environment (Zhang, 2013). The import of SHC is forbidden in China (Mofcom.gov.cn, 2002); therefore, this study aims to understand consumers' intention to purchase SHC among Young consumers rather than tracking actual purchase behavior. The study aligns with the twelfth and thirteenth five-year Chinese development plan to reuse, recycle, and environmental sustainability (Miit.gov.cn, 2017).

\section{Online Survey Method}

The questionnaire was uploaded from the Chinese platform www.wenjuan.com, an online service that provides survey construction, distribution, management, and analysis services. All participants gave their informed consent by checking a specific box. In return, the confidentiality of the identity of the participants is guaranteed. The volunteer and purposive snowball sampling techniques were used to collect data for this research. Additionally, The questionnaire was distributed to the Chinese people, and only respondents with prior experience buying second-hand products were counted (with the help of an initial question "Do you have experience buying second-hand products online?". Participants were recruited from Xianyu and Zhuan Zhuan online platforms, China's popular online second-hand product markets. Three hundred fourteen operational e-forms were collected from research respondents-data obtained in November and December 2019.

The questionnaire consisted of demographic questions related to the respondents' SHC shopping experience, age, education, income, and research questions. Initially, the questionnaire advanced in the English language, and then through three Chinese scholars, it got translated into the Chinese language. To ensure the reliability, validity, and clear understanding of the questionnaire's translated version, we did a pilot study of 30 voluntary participants. As suggested by the participant's slight fluctuations were done in the questionnaire and its translation. The sample size is enough for the analysis conducted (Hoelter, 1983; Majchrzak et al., 2005). Further to validate the research sample, we did power analysis using the G-power tool. A priory and post hoc power analysis results represented the complete adequacy of the sample size used by suggesting one hundred nineteen sample size as the required sample size (Faul et al., 2007).

\section{Sample Characteristics}

The research respondent sample's demographic characteristics regarding age, education, and family income are discussed. The total sample size is 314 respondents; the research questionnaire included the screening question about buying intention of second-hand products online, so only respondents who already have the experience were included in the sample. Respondents' age ranged from under 18 years to 64 and above, and most of the respondents ( 247 respondents, almost 79\%) were under 33 years and represented young Chinese consumers. $69 \%$ of the respondents have a university education level. 87\% (273 respondents) have a family income between $¥ 5,000-¥ 30,000$.

\section{Measurement}

For measuring the study constructs of mindful consumption (Baer et al., 2006), social norms (Hsu \& Lin, 2008; Venkatesh \& Davis, 2000), Ego-involvement (Ganesh et al., 2000), and buying intentions of second-hand goods (Ajzen, 2005). All the scale items have been adapted from the previous literature. The 7-Point Likert scale was used to measure all the items that ranged from "strongly disagree" to "strongly agree."

\section{Analysis Techniques}

The PLS-SEM (structural equation modeling) technique analyzed the empirical data to test the hypothesized statements in the current empirical research. As suggested by Hair et al. (2019) and Dash and Paul (2021), measurement and structural model steps are adapted for tests. The PLSSEM approach is best for exploratory types of research (Hair et al., 2017a; b) and has a high power of statistical inferences. The following section details descriptive and inferential statistical and explains the findings and results of the data. 


\section{Results}

Partial least squares-Structural equation modeling (PLSSEM) technique was performed using the SmartPLS-3 statistical package. All the measurement and structural model steps have been followed as suggested by Hair et al. (2019) for both techniques (Table 1).

\section{Measurement Model}

Reliabilities Item reliability is measured through loadings, and values above 0.708 are considered suitable, means construct explains $>50 \%$ indicator's variance. The threshold value for the item's reliability is 0.60 (Hair et al., 2011). All the research items used have factor loadings above 0.60 threshold level, thus proving the reliability of the items.
Internal consistency reliability can be measured using Cronbach alpha, rho_A, and composite reliability (Hair et al., 2019). It ensures the internal consistency of the data. Internal consistency reliability values in-between 0.70 to 0.90 considered decent values. However, values above 0.95 are not considered reasonable, dropping the construct validity (Hair et al., 2019). All the values in the current research are above the threshold level of 0.70 . (See Table 2).

Validities Validities are measured through convergent and discriminant validity values. Convergent validity explains to what extent the construct converges to explain the extent of the variance of its items, and the tool used is average variance extracted (AVE). The threshold value for AVE is above or equal to 0.50 and attained by the research (Bagozzi \& Yi, 1988; Hair et al., 2019). Discriminant validity calculates the extent of difference of one construct from other constructs of

Table 1 Discriminant Validities

\begin{tabular}{|c|c|c|c|c|}
\hline & 1 & 2 & 3 & 4 \\
\hline \multicolumn{5}{|c|}{ Fornell and Larcker Criterion } \\
\hline 1. Ego Involvement & .859 & & & \\
\hline 2. Mindfulness & .545 & .820 & & \\
\hline 3. SHC Buying Intentions & .520 & .429 & .859 & \\
\hline 4. Social Norms & .378 & .204 & .492 & .831 \\
\hline \multicolumn{5}{|c|}{ HTMT, Heterotrait-Monotrait Criterion } \\
\hline 1. Ego Involvement & & & & \\
\hline 2. Mindfulness & .690 & & & \\
\hline 3. SHC Buying Intentions & .630 & .534 & & \\
\hline 4. Social Norms & .473 & .276 & .621 & \\
\hline
\end{tabular}

The bold italic values and shaded boxes (the standard way of presenting HTMT criterion) diagonal values are the square roots of the AVE, and the off-diagonal values are the correlations

Table 2 Reliabilities, Validities \& VIF Values

\begin{tabular}{|c|c|c|c|c|c|c|}
\hline Construct with Items & FL & $\alpha$ & rho_A & $\mathrm{CR}$ & AVE & VIF \\
\hline Mindfulness & & .757 & .769 & .860 & .673 & \\
\hline MCl. I pay attention to how my emotions affect my behavior about buying second-hand clothing & .850 & & & & & 1.374 \\
\hline MC3. I criticize myself for having irrational or inappropriate emotions about second-hand clothing & .770 & & & & & 1.923 \\
\hline MC4. I am good at finding words to describe my feelings about second-hand clothing & .838 & & & & & 2.257 \\
\hline Ego-Involvement & & .822 & .826 & .894 & .738 & \\
\hline $\begin{array}{l}\text { EGO1. The image of the second-hand clothing plays a major role in my decision to become a user } \\
\text { of second-hand clothing }\end{array}$ & .883 & & & & & 2.128 \\
\hline EGO2. The second-hand clothing, I use says a lot about who I am & .874 & & & & & 1.985 \\
\hline EGO3. It is important for me to choose second-hand clothing that feels right & .818 & & & & & 1.632 \\
\hline Social Norms & & .773 & .786 & .869 & .691 & \\
\hline SN1. The trend of buying second-hand clothing among people around me is increasing & .736 & & & & & 1.374 \\
\hline SN2. My close friends and family members would appreciate it if I bought second-hand clothing & .848 & & & & & 1.923 \\
\hline SN3. People who are important to me think that I should use second-hand clothing & .902 & & & & & 2.257 \\
\hline SHC Buying Intention & & .820 & .822 & 894 & .738 & \\
\hline CC1. I have the intention to increase second-hand clothing consumption in the near future & .855 & & & & & 2.101 \\
\hline$C C 2$. Second-hand clothing will be the central part of my consumption in the future & .914 & & & & & 2.683 \\
\hline CC3. I would prefer to buy second-hand clothing to reduce environmental damage & .805 & & & & & 1.632 \\
\hline
\end{tabular}

FLFactor Loading, $\alpha$ Cronbach Alpha, CR Composite Reliability, AVE Average Variance Extracted, VIF Variance Inflation Factor 
the same model. It comprises that to what extent a variable is empirically different from the other variable in the framework (Hair et al., 2019). It is measured using two famous methods of Fornell and Larcker (Fornell \& Larcker, 1981) and Heterotrait-Monotrait (HTMT) ratio (Voorhees et al., 2016). (See Tables 1 and 2).

Multicollinearity \& Common Method Bias Multicollinearity and common method bias issues are assessed through VIF values in PLS-SEM, and values under the threshold of 5 prove no issues (Chin, 1998; Hair et al., 2011; Podsakoff et al., 2003). To validate further, we calculated Harman's single factor test and found the value of 17.621 less than the threshold of 50\% (Aguirre-Urreta \& Hu, 2019; Podsakoff et al., 2003). (See Table 2).

\section{Structural Model}

Explanatory/Predictive Power of Model The explanatory power of the research model is measured using the coefficient of determination $\left(\mathrm{R}^{2}\right)$, effect size $\left(\mathrm{f}^{2}\right)$, and predictive relevance $\left(Q^{2}\right)$. $R^{2}$ measures the variance of each endogenous variable (Shmueli \& Koppius, 2011). $\mathrm{R}^{2}$ value as 0.75 is considered good, 0.50 considered normal, and 0.25 considered weak (Hair et al., 2011; Henseler et al., 2009). In the current research, ego-involvement, social norms, and SHC buying intention and their $\mathrm{R}^{2}$ values are $0.294,0.140$, and 0.397 , respectively. The effect size is somehow redundant to the size of path coefficients. The threshold values of $\mathrm{f}^{2}$ are 0.02 as small, 0.15 as a medium, and 0.35 as large effect sizes (Cohen, 2013). Another way to assess the PLSSEM path model's predictive accuracy is $\mathrm{Q}^{2}$ and calculated through a blindfolding test (Geisser, 1974; Stone, 1974). The threshold values of $\mathrm{Q}^{2}$ are 0.02 as small, 0.15 as a medium, and 0.35 as large. (See Table 3).

Model Fit Indices SmartPLS3 shows some critical values for the model fit, i.e., SRMR, d_ULS, d_G, and NFI, and their results are $0.090,0.631,0.260$, and 0.721 , respectively (Dash \& Paul, 2021; Hair et al., 2019). All values provided satisfactory results to prove the current model fit for research. The study further computed goodness of fit (GOF), as suggested by Tenenhaus et al. (2005), to analyze the overall quality of the proposed framework. The obtained value of GOF is 0.443 , which is higher than the threshold value of 0.36 (Wetzels et al., 2009). (See Table 3).

Path Coefficients The last part of the structural model presents the statistical significance and relevance of path coefficient results (Hair et al., 2019). Table 4 and Figs. 1 and 2 displayed that mindful consumption positively and significantly affect SHC buying intention and ego-involvement, supporting hypotheses $\mathrm{H} 1$ and $\mathrm{H} 2$ (mindful consumption $\rightarrow \mathrm{SHC}$
Table $3 \mathrm{R}^{2}, \mathrm{Q}^{2}, \mathrm{f}^{2}$ \& Model Fit Indices

\begin{tabular}{llllll}
\hline & 1 & 2 & 3 & 4 & $\begin{array}{l}\text { Model } \\
\text { Fit } \\
\text { Indices }\end{array}$ \\
\hline $\mathrm{R}^{2}$ & & & & & \\
$\mathrm{Q}^{2}$ & - & .294 & .140 & .397 & \\
$\mathrm{f}^{2}$ & - & .207 & .092 & .278 & \\
1. Mindfulness & - & .422 & - & .051 & \\
2. Ego Involvement & - & - & .167 & .081 & \\
3. Social Norms & - & - & - & .171 & \\
4. SHC Buying Intention & & & & & \\
SRMR & - & - & - & - & .090 \\
d_ULS & - & - & - & - & .631 \\
d_G & - & - & - & - & .260 \\
NFI & - & - & - & - & .721 \\
GoF & - & - & - & - & .443 \\
\hline
\end{tabular}

buying intention: $\beta=0.202 * *$; mindful consumption $\rightarrow$ egoinvolvement: $\beta=0.545^{* * *}$ ). Ego-involvement positively and significantly impact SHC buying intention and social norm, supporting the hypothesis $\mathrm{H} 3$ and $\mathrm{H} 4$ (ego-involvement $\rightarrow$ SHC buying intention: $\beta=0.277^{* * *}$; ego-involvement $\rightarrow$ social norm: $\left.\beta=0.378^{* * *}\right)$. Social norm has a positive and significant impact on SHC buying intention (social norm $\rightarrow$ SHC buying intention: $\beta=0.351^{* * *}$ ), thus supporting the H5. Furthermore, the mediating relationships results of H6a (mindful consumption $\rightarrow$ ego-involvement $\rightarrow$ SHC buying intention: $\beta=0.151^{* * *}$ ) and $\mathrm{H} 6 \mathrm{~b}$ (ego-involvement $\rightarrow$ social norm $\rightarrow$ SHC buying intention: $\beta=0.133^{* * *}$ ) are proved positive and significant too. The study data approves all the hypothesized relationships based on statistical results. (See Table 4 \& Fig. 2).

Importance Performance Map Analysis IPMA identifies the antecedents having high performance but low importance and vice versa (Ringle \& Sarstedt, 2016). Figure 3 and Table 5 indicate that the research model constructs are highly performing. It represents the relationship between constructs' performance and importance. A unit point increase in the performance of the predecessor variable brings the performance increase by the size of its importance for the target construct (Ringle \& Sarstedt, 2016). SHC buying intention is the target variable in current research predicted by mindful consumption, ego-involvement, and social norm. The results show that "mindful consumption" has the most significant importance score $(0.425)$, which predicts that if the consumers improve their mindful consumption performance by a unit, their total SHC buying intention will Improve by 0.425 (ceteris paribus). Further, it shows that the consumers have the lowest social norm performance 
Table 4 Path Coefficients Results

\begin{tabular}{|c|c|c|c|c|c|c|}
\hline \# & Hypothesis Statements & $\begin{array}{l}\text { Paths Coef- } \\
\text { ficients }\end{array}$ & $\begin{array}{l}\text { Standard } \\
\text { Deviation }\end{array}$ & T Statistics & P Value & Action Taken \\
\hline \multicolumn{7}{|c|}{ Straight Relations } \\
\hline H1 & $\mathrm{MC} \rightarrow \mathrm{SHC}$ & .202 & .061 & 3.333 & .001 & Accepted \\
\hline $\mathrm{H} 2$ & $\mathrm{MC} \rightarrow \mathrm{EGO}$ & .545 & .039 & 13.899 & .000 & Accepted \\
\hline H3 & $\mathrm{EGO} \rightarrow \mathrm{SHC}$ & .277 & .055 & 5.056 & .000 & Accepted \\
\hline $\mathrm{H} 4$ & $\mathrm{EGO} \rightarrow \mathrm{SN}$ & .378 & .067 & 5.616 & .000 & Accepted \\
\hline H5 & $\mathrm{SN} \rightarrow \mathrm{SHC}$ & .351 & .040 & 8.849 & .000 & Accepted \\
\hline \multicolumn{7}{|c|}{ Mediation Relations } \\
\hline H6a & $\mathrm{MC} \rightarrow \mathrm{EGO} \rightarrow \mathrm{SHC}$ & .151 & .033 & 4.618 & .000 & Accepted \\
\hline $\mathrm{H} 6 \mathrm{~b}$ & $\mathrm{EGO} \rightarrow \mathrm{SN} \rightarrow \mathrm{SHC}$ & .133 & .032 & 4.171 & .000 & Accepted \\
\hline
\end{tabular}

$M C$ Mindful consumption, SHC Second-hand clothes intentions, EGO Ego-involvement, $S N$ Social norms

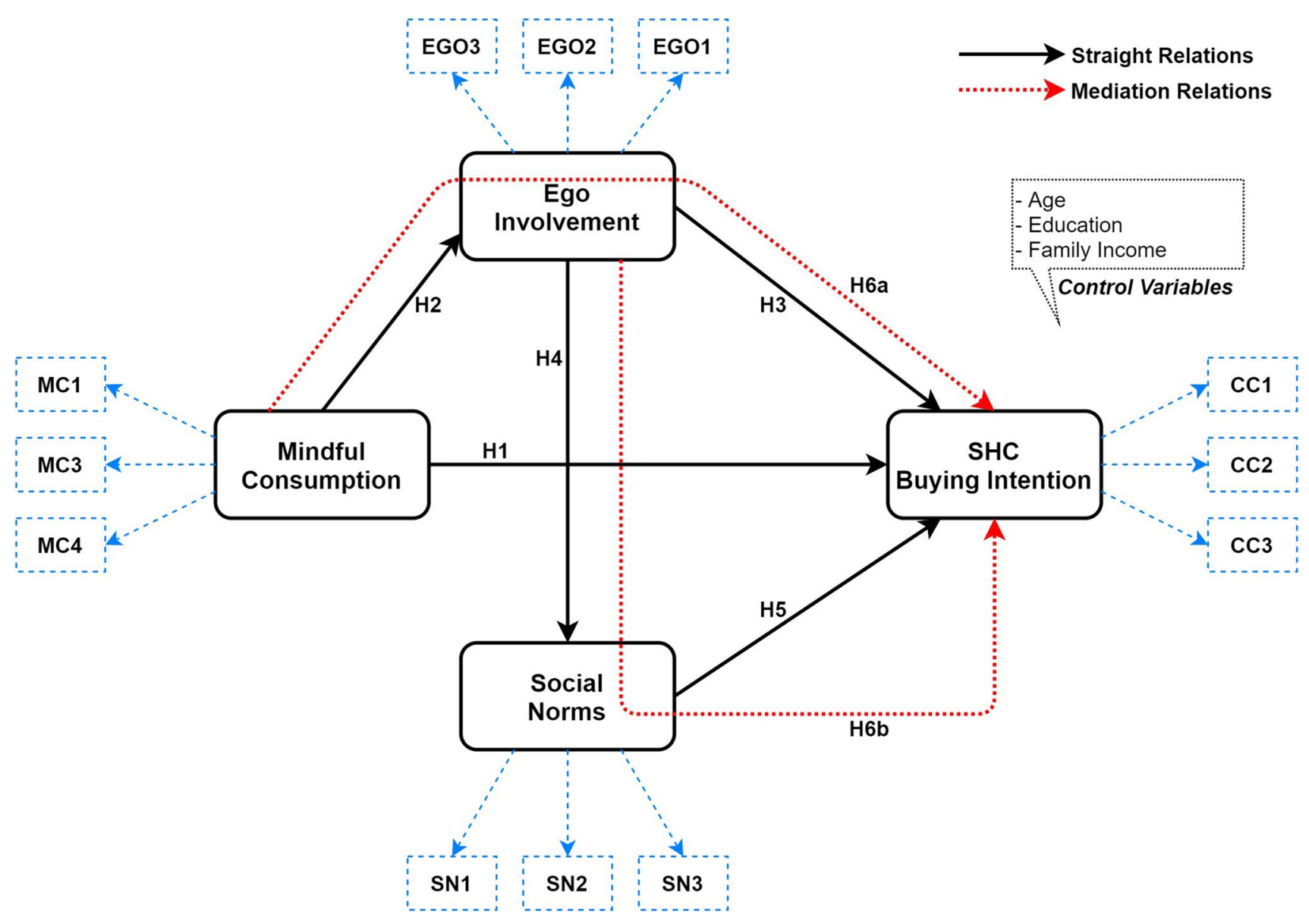

Fig. 1 Conceptual Framework

(40.810), indicating a considerable opportunity to improve this area. (See Table 5 \& Fig. 3).

\section{Discussion and Conclusion}

This research, designed to examine purchase intention of second-hand clothing, contributes to unpacking the role of ego-involvement and social norms to influence mindful purchase intention. While the dominant view in 
Fig. 2 Importance-Performance Map

Fig. 3 Factor Loading and Path Coefficients
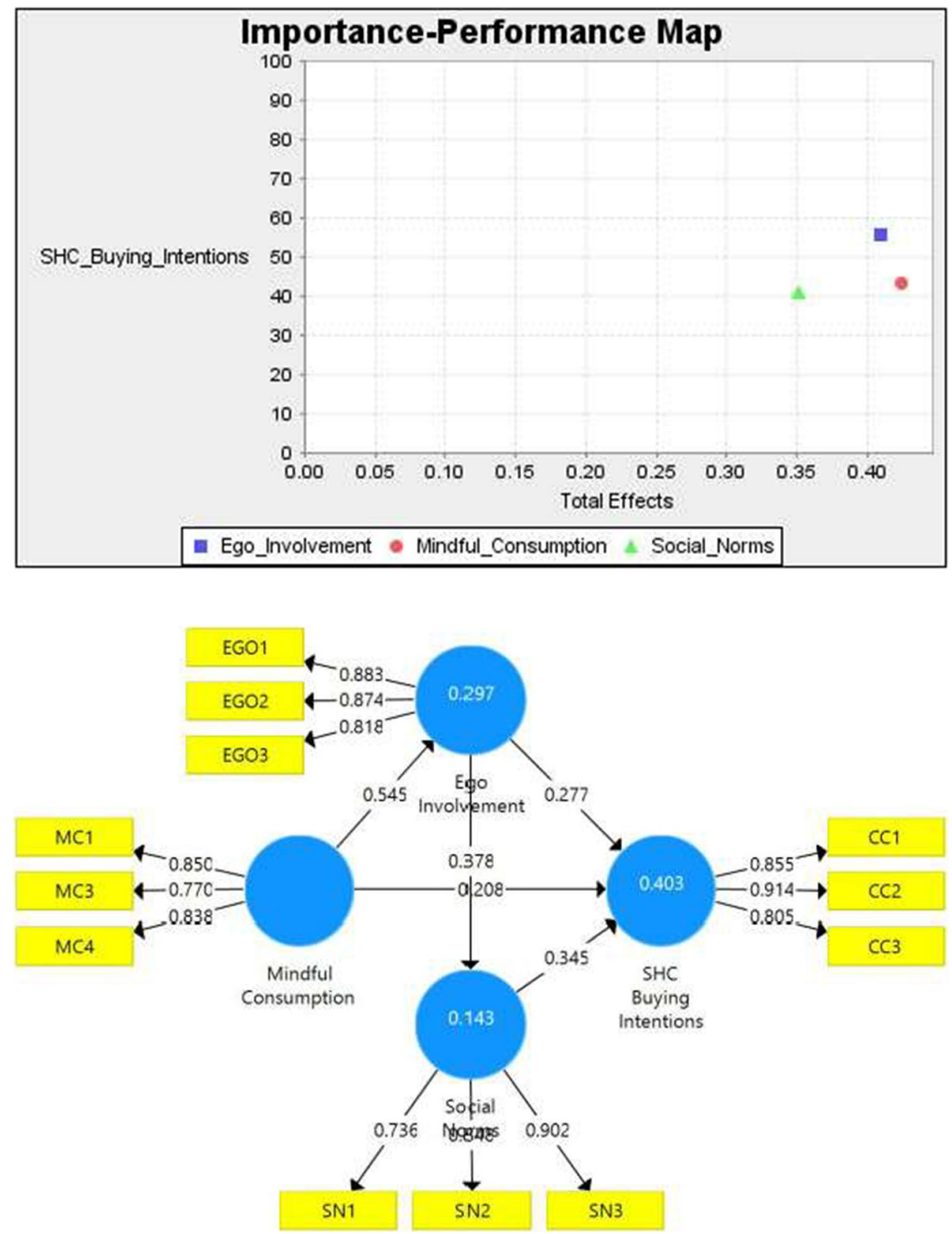

Table 5 IPMA Graph of SHC Buying Intention

\begin{tabular}{lll}
\hline Constructs & Importance & Performance \\
\hline Mindfulness & $\mathbf{. 4 2 5}$ & 43.335 \\
Ego Involvement & .410 & $\mathbf{5 5 . 7 5 7}$ \\
Social Norms & .351 & 40.810 \\
\hline
\end{tabular}

sustainability literature is that motivation to purchase second-hand clothing rest on economic benefit or concern for the planet (Khan \& Rundle-Thiele, 2019), our data show this model is simplistic and does not explain the drivers that may be influencing the behaviour. This research provides a novel explanation that ego involvement seems to mediate the relationship between mindfulness and purchase intention of SHC. Mindfulness alone is not enough to drive sustainability; however, when mindful thinking influences self-conscious emotions such as pride and guilt of actions towards self, society, and environment seem to stir people's ego involvement, hence sustainable purchase intention. Secondly, the research contributes to understanding the vital role of social norms in the relationship between ego-involvement and purchase intention of SHC.

This study elaborated the relationship between mindful consumption and SHC buying intention by proving a positive and significant relation aligning with previous literature 
(Mohammad et al., 2020). It shows that Young Chinese consumers are familiar with sustainability and influenced by the Buddhism beliefs, arising intrinsic motivations would be more tilted towards the sustainable behavior of buying SHC that is the response of their extrinsic motivation. It validates the self-determination theory application in the relationship of mindful consumption and SHC buying intentions. Secondly, mindfulness leads to ego-involvement and builds a firm commitment towards sustainability in young consumers by proving the relationship between conscious consumption and ego-involvement. Thirdly, the research confirmed the association of ego-involvement towards buying SHC (McNeill \& Venter, 2019) and social norms (Vansteenkiste 2007a, b). Young consumers' commitment to sustainability through buying SHC proves the social judgment theory application and elaborates that consumers evaluate sustainable values/beliefs and act accordingly in their best interest.

Moreover, the consumers want their social circle (family, friends, or peers) to behave similarly to buy SHC so these consumers can satisfy their self-esteem. The social norms contribution is noted in buying intention of SHC (Borusiak et al., 2020). Young consumers are influenced by their family, friends, and peers, and this influence is leading them to comply with sustainable practices and increase buying SHC.

The current study raises an important point that environmental concern drives Western countries' sustainable behavior seated on individualist cultural values. Khan and RundleThiele (2019) and Chu et al. (2018) delineate the idea that environmental concern plays an essential role in motivating Chinese consumers to sustainable purchase behavior. As an alternative to this debate, by applying social judgment theory and self-determination, our research positioned mindfulness and ego and social norms as essential attributes to influence the purchase intention of SHC in China. This research aligns with Khan and Rundle-Thiele (2019) and Padmavathy et al. (2019) that the purchase of used clothes is related to economic benefits on the one hand for those who are concerned about saving money. The other group of young consumers is motivated to buy SHC as they reduce the number of new garments manufactured, an attribute close to mindfulness.

This research utilised self-determination theory to explain the unique finding and the postulated relationship between mindfulness, ego-involvement, and social norm as predictors of SHC purchase intention. It is a comprehensive framework for understanding young consumers' mindfulness and belongingness to the social group, and their feeling of responsibility influences the SHC market.

Social norms are firmly instilled in Chinese culture and profoundly impact young Chinese consumers' buying intentions (Barnes \& Mattsson, 2017). Current work consolidates the previous literature as it shows that social agents (family, friends, and peers) impact consumers' intentions. The significant others can influence youngsters to protect the natural environment and increase sustainable behavior. Current work consolidates the previous literature as it shows that social agents (family, friends, and peers) impact consumers' intentions. The significant others can influence youngsters to protect the natural environment and increase sustainable behavior.

\section{Theoretical and Practical Implications}

Consumers express their liking and interests in social media platforms, creating word of mouth, whereas these word of mouths are aspects of digital social norms binding people to act cohesively to environmental sustainability. Positive word of mouth of SHC in social media influences individuals' ego involvement on this issue and arouse mindfulness. Young consumers fancy social media and share SHC information with friends and family, diffusing the new trend of SHC faster. Entrepreneurs and companies encourage young consumers to develop this new consumption model, reusing and recycling based on society's environmental benefit.

The ego-involvement of young consumers influences buying SHC since the act enhances their self-esteem (Lai \& Chen, 2011). A feeling of responsibility and commitment to purchase SHC is the marketing communication message that companies can focus on while communicating with their target audience, the prospective buyer of SHC. This study supports the idea that mindfulness enhances pro-environment behavior-the findings highlight formative social marketing programs that improve conscious consumption behavior. Mindfulness is deeply rooted in Buddhist teaching that government agencies and regulators run social marketing programs to touch consumers' hearts and minds from all walks of life. Enhancing the idea of mindfulness brings harmony to society and results in sustainable consumption behavior. The ego involvement of young consumers influences buying SHC since it enhances their self-esteem (Lai $\&$ Chen, 2011). A feeling of responsibility and commitment to purchase SHC is the marketing communication message that companies can focus on while communicating with their target audience, the prospective buyer of SHC.

\section{Limitations and Future Research}

The limitation of the study pertains to data. The current research mapped purchase intention rather than actual behavior as the context presented that the import and sale of SHC are restricted in the Chinese market. The data were collected using convenience sampling in a cross-sectional design. Future research recommended adopting a probability sampling technique and collecting data from an emerging market where import and use of SHC are encouraged by 
regulators. Future studies are encouraged to explore other possible factors, e.g., economic benefit, functional, social benefit, trust, reputation, environmental concern, and potential impact on the proposed relationships between the elements and actual spending on SHC.

Data availability The datasets generated during and/or analyzed during the current study are available from the corresponding author on reasonable request.

\section{Declarations}

Research involving Human Participants and/or Animals A online selfassessment called Self-Assessment for Governance and Ethics (SAGE) by university of surrey was performed by Dr. Jashim Khan (corresponding author). The self-assessment guided that the study did not involve animal as participant.

For survey research self-assessment also did not to raise any issue that may impact human participant. All study construct were sourced from secondary research and adopted to suit the purpose of research. There was no concern raised for animal or human harm by participating in this research.

Informed Consent Written informed consent was obtained from all participants in this study before commencing the survey.

Conflict of Interest On behalf of all authors, the corresponding author states that there is no conflict of interest.

Open Access This article is licensed under a Creative Commons Attribution 4.0 International License, which permits use, sharing, adaptation, distribution and reproduction in any medium or format, as long as you give appropriate credit to the original author(s) and the source, provide a link to the Creative Commons licence, and indicate if changes were made. The images or other third party material in this article are included in the article's Creative Commons licence, unless indicated otherwise in a credit line to the material. If material is not included in the article's Creative Commons licence and your intended use is not permitted by statutory regulation or exceeds the permitted use, you will need to obtain permission directly from the copyright holder. To view a copy of this licence, visit http://creativecommons.org/licenses/by/4.0/.

\section{References}

Abbasi, L., \& Akhlaghi-fard, M. (2021). The effectiveness of mindfulness training on ego-strength and meta-cognitive beliefs of students. Journal of Social Sciences and Humanities Research, 9(01), 12-26.

Aguirre-Urreta, M. I., \& Hu, J. (2019). Detecting common method bias: Performance of the Harman's single-factor test. ACM SIGMIS Database: The DATABASE for Advances in Information Systems, 50(2), 45-70.

Ajzen, I. (1991). The theory of planned behavior. Organizational Behavior and Human Decision Processes, 50(2), 179-211.

Ajzen, I. (2005). Attitudes, personality, and behavior. McGraw-Hill Education (UK)

Antonetti, P., \& Maklan, S. (2014). Feelings that make a difference: How guilt and pride convince consumers of the effectiveness of sustainable consumption choices. Journal of Business Ethics, 124(1), 117-134

Arslan, Ü., \& Asıc1, E. (2021). The mediating role of solution focused thinking in relation between mindfulness and psychological wellbeing in university students. Current Psychology, 1-10.

Baer, R. A., Smith, G. T., Hopkins, J., Krietemeyer, J., \& Toney, L. (2006). Using self-report assessment methods to explore facets of mindfulness. Assessment, 13(1), 27-45.

Bagozzi, R. P., \& Yi, Y. (1988). On the evaluation of structural equation models. Journal of the Academy of Marketing Science, 16(1), 74-94.

Barbaro, N., \& Pickett, S. M. (2016). Mindfully green: Examining the effect of connectedness to nature on the relationship between mindfulness and engagement in pro-environmental behavior. Personality and Individual Differences, 93, 137-142.

Barnes, S. J., \& Mattsson, J. (2017). Understanding collaborative consumption: Test of a theoretical model. Technological Forecasting and Social Change, 118, 281-292.

Becker-Leifhold, C., \& Iran, S. (2018). Collaborative fashion consumption-drivers, barriers and future pathways. Journal of Fashion Marketing and Management: An International Journal.

Beitel, M., Ferrer, E., \& Cecero, J. J. (2005). Psychological mindedness and awareness of self and others. Journal of Clinical Psychology, 61(6), 739-750.

Bennett, E. V., Clarke, L. H., Kowalski, K. C., \& Crocker, P. R. (2017). From pleasure and pride to the fear of decline: Exploring the emotions in older women's physical activity narratives. Psychology of Sport and Exercise, 33, 113-122.

Bergan, D. E. (2021). Does ability contribute to partisan bias?: Evaluating scientific research about political topics. Communication Studies, 1-16.

Bjurbäck, A. (2015). Environmental Benefits of Second Hand-shopping e Environ-mental Impacts of Clothes and the Benefits of the Emmaus Björkå Second-hand Business. Master's thesis. Gothenburg University, Sweden.

Borusiak, B., Szymkowiak, A., Horska, E., Raszka, N., \& Żelichowska, E. (2020). Towards building sustainable consumption: A study of second-hand buying intentions. Sustainability, 12(3), 875.

Botsman, R., \& Rogers, R. (2010). What's mine is yours. The rise of collaborative consumption.

Botsman, R., \& Rogers, R. (2011). What's mine is yours: how collaborative consumption is changing the way we live. In: $\mathrm{CD}$.

Brown, K. W., Ryan, R. M., \& Creswell, J. D. (2007). Mindfulness: Theoretical foundations and evidence for its salutary effects. Psychological Inquiry, 18(4), 211-237.

Brown, A. P., Marquis, A., \& Guiffrida, D. A. (2013). Mindfulnessbased interventions in counseling. Journal of Counseling \& Development, 91(1), 96-104.

Carpenter, C. J. (2019). Cognitive dissonance, ego-involvement, and motivated reasoning. Annals of the International Communication Association, 43(1), 1-23.

Carpenter, C. J., \& Cruz, S. M. (2021). Promoting climate change abatement policies in the face of motivated reasoning: Oneness with the source and attitude generalization. International Journal of Communication, 15, 21.

Carson, S. H., \& Langer, E. J. (2006). Mindfulness and self-acceptance. Journal of Rational-Emotive and Cognitive-Behavior Therapy, 24(1), 29-43.

Cater, B., \& Zabkar, V. (2009). Antecedents and consequences of commitment in marketing research services: The client's perspective. Industrial Marketing Management, 38(7), 785-797.

Čater, T., \& Čater, B. (2010). Product and relationship quality influence on customer commitment and loyalty in B2B manufacturing relationships. Industrial Marketing Management, 39(8), 1321-1333.

Cervellon, M.-C., Carey, L., \& Harms, T. (2012). Something old, something used: Determinants of women's purchase of vintage 
fashion vs second-hand fashion. International Journal of Retail \& Distribution Management, 40(12), 956-974.

Chang, H. H., \& Chuang, S.-S. (2011). Social capital and individual motivations on knowledge sharing: Participant involvement as a moderator. Information \& Management, 48(1), 9-18.

Chin, W. W. (1998). Commentary: Issues and opinion on structural equation modeling. In: JSTOR.

Chu, W., Baumann, C., Hamin, H., \& Hoadley, S. (2018). Adoption of environment-friendly cars: Direct vis-à-vis mediated effects of government incentives and consumers' environmental concern across global car markets. Journal of Global Marketing, 31(4), 282-291.

Cohen, J. (2013). Statistical power analysis for the behavioral sciences. Routledge.

Dash, G., \& Paul, J. (2021). CB-SEM vs PLS-SEM methods for research in social sciences and technology forecasting. Technological Forecasting and Social Change, 173, 121092.

De Charms, R. (1968). Personal causation: The international affective determinations of behavior. Press.

Deci, E. L. (1985). 8: Ryan, RM (1985) Intrinsic motivation and selfdetermination in human behavior. Plenum.

Deci, E. L., \& Ryan, R. M. (1991). A motivational approach to self: Integration in personality.

Deci, E. L., \& Ryan, R. M. (2000). The" what" and" why" of goal pursuits: Human needs and the self-determination of behavior. Psychological Inquiry, 11(4), 227-268.

Deci, E. L., \& Ryan, R. M. (2012). Self-determination theory.

Dekeyser, M., Raes, F., Leijssen, M., Leysen, S., \& Dewulf, D. (2008). Mindfulness skills and interpersonal behaviour. Personality and Individual Differences, 44(5), 1235-1245.

Dhandra, T. K. (2019). Achieving triple dividend through mindfulness: More sustainable consumption, less unsustainable consumption and more life satisfaction. Ecological Economics, 161, 83-90.

Dixit, S., Badgaiyan, A. J., \& Khare, A. (2019). An integrated model for predicting consumer's intention to write online reviews. Journal of Retailing and Consumer Services, 46, 112-120.

Donald, J. N., Sahdra, B. K., Van Zanden, B., Duineveld, J. J., Atkins, P. W., Marshall, S. L., \& Ciarrochi, J. (2019). Does your mindfulness benefit others? A systematic review and meta-analysis of the link between mindfulness and prosocial behaviour. British Journal of Psychology, 110(1), 101-125.

Eagly, A. H., \& Chaiken, S. (1993). The psychology of attitudes. Harcourt brace Jovanovich college publishers.

Elliot, A. J. (2005). A conceptual history of the achievement goal construct.

Ericson, T., Kjønstad, B. G., \& Barstad, A. (2014). Mindfulness and Sustainability. Ecological Economics, 104, 73-79.

Faul, F., Erdfelder, E., Lang, A.-G., \& Buchner, A. (2007). G* Power 3: A flexible statistical power analysis program for the social, behavioral, and biomedical sciences. Behavior Research Methods, 39(2), 175-191.

Fischer, D., Stanszus, L., Geiger, S., Grossman, P., \& Schrader, U. (2017). Mindfulness and sustainable consumption: A systematic literature review of research approaches and findings. Journal of Cleaner Production, 162, 544-558.

Fishbein, M., \& Ajzen, I. (1975). Belief, attitude, intention and behavior: An introduction to theory and research.

Fornell, C., \& Larcker, D. F. (1981). Structural equation models with unobservable variables and measurement error: Algebra and statistics. Journal of Marketing Research, 18, 382-388.

Frewen, P. A., Evans, E. M., Maraj, N., Dozois, D. J., \& Partridge, K. (2008). Letting go: Mindfulness and negative automatic thinking. Cognitive Therapy and Research, 32(6), 758-774.

Friese, M., Messner, C., \& Schaffner, Y. (2012). Mindfulness meditation counteracts self-control depletion. Consciousness and Cognition, 21(2), 1016-1022.
Ganesh, J., Arnold, M. J., \& Reynolds, K. E. (2000). Understanding the customer base of service providers: An examination of the differences between switchers and stayers. Journal of Marketing, 64(3), 65-87.

Gao, X., Xu, X.-Y., Tayyab, S. M. U., \& Li, Q. (2021). How the live streaming commerce viewers process the persuasive message: An ELM perspective and the moderating effect of mindfulness. Electronic Commerce Research and Applications, 49, 101087.

Geiger, S. M., Grossman, P., \& Schrader, U. (2018). Mindfulness and sustainability: Correlation or causation? Current Opinion in Psychology.

Geisser, S. (1974). A predictive approach to the random effect model. Biometrika, 61(1), 101-107.

Goldfarb, Y., Golan, O., \& Gal, E. (2021). A self-determination theory approach to work motivation of autistic adults: A qualitative exploratory study. Journal of autism and developmental disorders, 1-14.

Goleman, D., \& Davidson, R. J. (2017). Altered traits: Science reveals how meditation changes your mind, brain, and body. Penguin.

Grossman, P. (2010). Mindfulness for psychologists: Paying kind attention to the perceptible. Mindfulness, 1(2), 87-97.

Hair, J. F., Ringle, C. M., \& Sarstedt, M. (2011). PLS-SEM: Indeed a silver bullet. Journal of Marketing Theory and Practice, 19(2), $139-152$.

Hair, J., Hollingsworth, C. L., Randolph, A. B., \& Chong, A. Y. L. (2017a). An updated and expanded assessment of PLS-SEM in information systems research. Industrial management \& data systems.

Hair, J. F., Jr., Matthews, L. M., Matthews, R. L., \& Sarstedt, M. (2017b). PLS-SEM or CB-SEM: Updated guidelines on which method to use. International Journal of Multivariate Data Analysis, 1(2), 107-123.

Hair, J. F., Risher, J. J., Sarstedt, M., \& Ringle, C. M. (2019). When to use and how to report the results of PLS-SEM. European business review.

Hakan, R. L., Neal, J. M., \& Lothes, J. (2017). Social judgments as a measure of right mindfulness. SAGE Open, 7(1), 2158244016686811.

Henseler, J., Ringle, C. M., \& Sinkovics, R. R. (2009). The use of partial least squares path modeling in international marketing. Emerald Group Publishing Limited.

Heppner, W. L., Kernis, M. H., Lakey, C. E., Campbell, W. K., Goldman, B. M., Davis, P. J., \& Cascio, E. V. (2008). Mindfulness as a means of reducing aggressive behavior: Dispositional and situational evidence. Aggressive Behavior: Official Journal of the International Society for Research on Aggression, 34(5), 486-496.

Hinshelwood, R. (1995). The social relocation of personal identity as shown by psychoanalytic observations of splitting, projection, and introjection. Philosophy, Psychiatry, \& Psychology, 2(3), 185-204.

Hoelter, J. W. (1983). The analysis of covariance structures: Goodness-of-fit indices. Sociological Methods \& Research, 11(3), $325-344$.

Howard, J. L., Bureau, J., Guay, F., Chong, J. X., \& Ryan, R. M. (2021). Student motivation and associated outcomes: A metaanalysis from self-determination theory. Perspectives on Psychological Science, 1745691620966789.

Hsu, C.-L., \& Lin, J.C.-C. (2008). Acceptance of blog usage: The roles of technology acceptance, social influence and knowledge sharing motivation. Information \& Management, 45(1), 65-74.

Hwang, K., \& Lee, B. (2019). Pride, mindfulness, public self-awareness, affective satisfaction, and customer citizenship behaviour among green restaurant customers. International Journal of Hospitality Management, 83, 169-179. 
Iran, S., \& Schrader, U. (2017). Collaborative fashion consumption and its environmental effects. Journal of Fashion Marketing and Management: An International Journal.

Jacob, J., Jovic, E., \& Brinkerhoff, M. B. (2009). Personal and planetary well-being: Mindfulness meditation, pro-environmental behavior and personal quality of life in a survey from the social justice and ecological sustainability movement. Social Indicators Research, 93(2), 275-294.

Jakobsen, A. M. (2021). The relationship between motivation, perceived motivational climate, task and ego orientation, and perceived coach autonomy in young ice hockey players.

Jin, J., Zhao, Q., \& Santibanez-Gonzalez, E. D. (2020). How Chinese consumers' intentions for purchasing eco-labeled products are influenced by psychological factors. International Journal of Environmental Research and Public Health, 17(1), 265.

Johnson, B. T., \& Eagly, A. H. (1989). Effects of involvement on persuasion: A meta-analysis. Psychological Bulletin, 106(2), 290.

Johnson, D. P., Penn, D. L., Fredrickson, B. L., Meyer, P. S., Kring, A. M., \& Brantley, M. (2009). Loving-kindness meditation to enhance recovery from negative symptoms of schizophrenia. Journal of Clinical Psychology, 65(5), 499-509.

Jung, H. J., Choi, Y. J., \& Oh, K. W. (2020). Influencing factors of Chinese consumers' purchase intention to sustainable apparel products: Exploring consumer "attitude-behavioral intention" gap. Sustainability, 12(5), 1770.

Kasser, T., \& Ryan, R. M. (1996). Further examining the American dream: Differential correlates of intrinsic and extrinsic goals. Personality and Social Psychology Bulletin, 22(3), 280-287.

Khan, J., \& Rundle-Thiele, S. (2019). Factors explaining shared clothes consumption in China: Individual benefit or planet concern? International Journal of Nonprofit and Voluntary Sector Marketing, 24(4), e1652.

Kim, Y., Sohn, D., \& Choi, S. M. (2011). Cultural difference in motivations for using social network sites: A comparative study of American and Korean college students. Computers in Human Behavior, 27(1), 365-372.

Knight Lapinski, M., \& Boster, F. J. (2001). Modeling the ego-defensive function of attitudes. Communication Monographs, 68(3), 314-324.

Lai, W.-T., \& Chen, C.-F. (2011). Behavioral intentions of public transit passengers-The roles of service quality, perceived value, satisfaction and involvement. Transport Policy, 18(2), 318-325.

Lang, C., \& Zhang, R. (2019). Second-hand clothing acquisition: The motivations and barriers to clothing swaps for Chinese consumers. Sustainable Production and Consumption, 18, 156-164.

Lapinski, M. K., \& Rimal, R. N. (2005). An explication of social norms. Communication Theory, 15(2), 127-147.

Leary, M. R., Adams, C. E., \& Tate, E. B. (2006). Hypo-egoic selfregulation: Exercising self-control by diminishing the influence of the self. Journal of Personality, 74(6), 1803-1832.

Liang, J., \& Xu, Y. (2018). Second-hand clothing consumption: A generational cohort analysis of the Chinese market. International Journal of Consumer Studies, 42(1), 120-130.

Liu, M., \& Valente, E. (2018). Psychology International.

Luberto, C. M., Shinday, N., Song, R., Philpotts, L. L., Park, E. R., Fricchione, G. L., \& Yeh, G. Y. (2018). A systematic review and meta-analysis of the effects of meditation on empathy, compassion, and prosocial behaviors. Mindfulness, 9(3), 708-724.

Luo, N., Wang, Y., Zhang, M., Niu, T., \& Tu, J. (2020). Integrating community and e-commerce to build a trusted online secondhand platform: Based on the perspective of social capital. Technological Forecasting and Social Change, 153, 119913.

Lykins, E. L. B. (2009). Effects of mindfulness and meditation experience on cognitive and emotional functioning and ego depletion.

Majchrzak, A., Malhotra, A., \& John, R. (2005). Perceived individual collaboration know-how development through information technology-enabled contextualization: Evidence from distributed teams. Information Systems Research, 16(1), 9-27.

McDermott, K. C., \& Lachlan, K. A. (2020). Polarizing organizations and image repair: The effects of extreme disposition and ego-involvement on ELM processing routes for organizational responses. Communication Studies, 71(2), 332-350.

McNeill, L., \& Venter, B. (2019). Identity, self-concept and young women's engagement with collaborative, sustainable fashion consumption models. International Journal of Consumer Studies, 43(4), 368-378.

Michaelidou, N., \& Dibb, S. (2008). Consumer involvement: A new perspective. The Marketing Review, 8(1), 83-99.

Miit.gov.cn. (2017). 工业和信息化部关于印发纺织工业发展规划 (2016-2020 年) 的通知[Notice of the Ministry of Industry and Information Technology on issuing the development plan for textile industry (2016-2020) ]. [online] Available at: http://www. miit.gov.cn/n1146295/n1652858/n1652930/n3757019/c5267 251/content.html

Milne, G. R., Villarroel Ordenes, F., \& Kaplan, B. (2020). Mindful consumption: Three consumer segment views. Australasian Marketing Journal, 28(1), 3-10.

Mofcom.gov.cn. (2002). 中华人民共和国对外贸易经济合作部、 中华人民共和国海关总署、中华人民共和国国家环境保护 总局公告 2002 年第 25 号——《禁止进口货物目录》(第 四批、第五批) [List of Prohibited Imports]. [online] Available at: http://www.mofcom.gov.cn/article/b/c/200404/2004040020 5769.shtml

Mohammad, J., Quoquab, F., \& Sadom, N. Z. M. (2020). Mindful consumption of second-hand clothing: the role of eWOM, attitude and consumer engagement. Journal of Fashion Marketing and Management: An International Journal.

Molden, D. C., Bayes, R., \& Druckman, J. N. (2021). A motivational systems approach to investigating opinions on climate change. Thinking \& Reasoning, 1-32.

Okur, N., \& Saricam, C. (2019). The Impact of Knowledge on Consumer Behaviour Towards Sustainable Apparel Consumption. In Consumer Behaviour and Sustainable Fashion Consumption (pp. 69-96). Springer.

Padmavathy, C., Swapana, M., \& Paul, J. (2019). Online second-hand shopping motivation-Conceptualization, scale development, and validation. Journal of Retailing and Consumer Services, 51, $19-32$.

Park, N., \& Yang, A. (2012). Online environmental community members' intention to participate in environmental activities: An application of the theory of planned behavior in the Chinese context. Computers in Human Behavior, 28(4), 1298-1306.

Park, N., Jung, Y., \& Lee, K. M. (2011). Intention to upload video content on the internet: The role of social norms and ego-involvement. Computers in Human Behavior, 27(5), 1996-2004.

Park, N., Oh, H. S., \& Kang, N. (2012). Factors influencing intention to upload content on Wikipedia in South Korea: The effects of social norms and individual differences. Computers in Human Behavior, 28(3), 898-905.

Park, N., Oh, H. S., \& Kang, N. (2015). Effects of ego involvement and social norms on individuals' uploading intention on W ikipedia: A comparative study between the U nited $\mathrm{S}$ tates and $\mathrm{S}$ outh $\mathrm{K}$ orea. Journal of the Association for Information Science and Technology, 66(7), 1494-1506.

Perloff, R. M. (1989). Ego-involvement and the third person effect of televised news coverage. Communication Research, 16(2), 236-262.

Peterson, L. G., \& Pbert, L. (1992). Effectiveness of a meditation-based stress reduction program in the treatment of anxiety disorders. American Journal of Psychiatry, 149(7), 936-943. 
Peterson, M., \& Simkins, T. (2019). Consumers' processing of mindful commercial car sharing. Business Strategy and the Environment, 28(3), 457-465.

Petty, R. E., Cacioppo, J. T., \& Haugtvedt, C. P. (1992). Ego-involvement and persuasion: An appreciative look at the Sherif's contribution to the study of self-relevance and attitude change. In Social judgment and intergroup relations (pp. 147-174). Springer.

Podsakoff, P. M., MacKenzie, S. B., Lee, J.-Y., \& Podsakoff, N. P. (2003). Common method biases in behavioral research: A critical review of the literature and recommended remedies. Journal of Applied Psychology, 88(5), 879.

Rawsthorne, L. J., \& Elliot, A. J. (1999). Achievement goals and intrinsic motivation: A meta-analytic review. Personality and Social Psychology Review, 3(4), 326-344.

Ringle, C. M., \& Sarstedt, M. (2016). Gain more insight from your PLS-SEM results: The importance-performance map analysis. Industrial management \& data systems.

Roux, D., \& Guiot, D. (2008). Measuring second-hand shopping motives, antecedents and consequences. Recherche Et Applications En Marketing (English Edition), 23(4), 63-91.

Ryan, R. M. (1982). Control and information in the intrapersonal sphere: An extension of cognitive evaluation theory. Journal of Personality and Social Psychology, 43(3), 450.

Ryan, R. M., \& Deci, E. L. (2000). Self-determination theory and the facilitation of intrinsic motivation, social development, and wellbeing. American Psychologist, 55(1), 68.

Ryan, R. M., \& Deci, E. L. (2017). Self-determination theory: Basic psychological needs in motivation, development, and wellness. Guilford Publications.

Sajjad, A., \& Shahbaz, W. (2020). Mindfulness and social sustainability: An integrative review. Social Indicators Research, 150(2), 73-94.

Sangharakshita. (2003). Living with awareness: A guide to the Satipațthāna Sutta. Windhorse Publications.

Schor, J. B., \& Fitzmaurice, C. J. (2015). Collaborating and connecting: The emergence of the sharing economy. Edward Elgar Publishing.

Schuman-Olivier, Z., Trombka, M., Lovas, D. A., Brewer, J. A., Vago, D. R., Gawande, R., ... Fulwiler, C. (2020). Mindfulness and behavior change. Harvard Review of Psychiatry.

Sherif, M., \& Cantril, H. (1947). The psychology of ego-involvements: Social attitudes and identifications.

Sherif, M., \& Hovland, C. I. (1961). Social judgment: Assimilation and contrast effects in communication and attitude change.

Sherif, M., \& Sherif, C. W. (1967). Attitude as the individual's own categories: The social judgment-involvement approach to attitude and attitude change. Attitude, ego-involvement, and change (pp. 105-139)

Sherif, C. W., Sherif, M., \& Nebergall, R. E. (1965). Attitude and attitude change: The social judgment-involvement approach. Saunders Philadelphia.

Sheth, J. N., Sethia, N. K., \& Srinivas, S. (2011). Mindful consumption: A customer-centric approach to sustainability. Journal of the Academy of Marketing Science, 39(1), 21-39.

Shmueli, G., \& Koppius, O. R. (2011). Predictive analytics in information systems research. MIS Quarterly, 35, 553-572.

Siero, F. W., \& Doosje, B. J. (1993). Attitude change following persuasive communication: Integrating social judgment theory and the elaboration likelihood model. European Journal of Social Psychology, 23(5), 541-554.

Sohn, S. H. (2010). Sex Differences in Social Comparison and Comparison Motives in Body Image Process. North American Journal of Psychology, 12(3).
Stone, M. (1974). Cross-validatory choice and assessment of statistical predictions. Journal of the Royal Statistical Society: Series B (Methodological), 36(2), 111-133.

Tangney, J. P. E., \& Fischer, K. W. (1995). Self-conscious emotions: The psychology of shame, guilt, embarrassment, and pride. The idea for this volume grew out of 2 pivotal conferences. The 1 st conference, on emotion and cognition in development, was held in Winter Park, CO, Sum 1985. The 2nd conference, on shame and other self-conscious emotions, was held in Asilomar, CA, Dec 1988.,

Tenenhaus, M., Vinzi, V. E., Chatelin, Y.-M., \& Lauro, C. (2005). PLS path modeling. Computational Statistics \& Data Analysis, 48(1), 159-205.

Vansteenkiste, M., Matos, L., Lens, W., \& Soenens, B. (2007a). Understanding the impact of intrinsic versus extrinsic goal framing on exercise performance: The conflicting role of task and ego involvement. Psychology of Sport and Exercise, 8(5), 771-794.

Vansteenkiste, M., Neyrinck, B., Niemiec, C. P., Soenens, B., De Witte, H., \& Van den Broeck, A. (2007b). On the relations among work value orientations, psychological need satisfaction and job outcomes: A self-determination theory approach. Journal of Occupational and Organizational Psychology, 80(2), 251-277.

Varshneya, G., Pandey, S. K., \& Das, G. (2017). Impact of social influence and green consumption values on purchase intention of organic clothing: A study on collectivist developing economy. Global Business Review, 18(2), 478-492.

Venkatesh, V., \& Davis, F. D. (2000). A theoretical extension of the technology acceptance model: Four longitudinal field studies. Management Science, 46(2), 186-204.

Voorhees, C. M., Brady, M. K., Calantone, R., \& Ramirez, E. (2016). Discriminant validity testing in marketing: An analysis, causes for concern, and proposed remedies. Journal of the Academy of Marketing Science, 44(1), 119-134.

Watson, D., Palm, D., Brix, L., Amstrup, M., Syversen, F., \& Nielsen, R. (2016). Exports of Nordic used textiles: fate, benefits and impacts. Nordic Council of Ministers.

Weil, C. (1999). Secondhand chic: Finding fabulous fashion at consignment, vintage, and thrift shops. Simon and Schuster.

Wetzels, M., Odekerken-Schröder, G., \& Van Oppen, C. (2009). Using PLS path modeling for assessing hierarchical construct models: Guidelines and empirical illustration. MIS quarterly, 33, 177-195.

Williams, G. C., Hedberg, V. A., Cox, E. M., \& Deci, E. L. (2000). Extrinsic life goals and health-risk behaviors in adolescents 1 . Journal of Applied Social Psychology, 30(8), 1756-1771.

Xu, Y., Chen, Y., Burman, R., \& Zhao, H. (2014). Second-hand clothing consumption: A cross-cultural comparison between A merican and $\mathrm{C}$ hinese young consumers. International Journal of Consumer Studies, 38(6), 670-677.

Yu, T.-K., Lu, L.-C., \& Liu, T.-F. (2010). Exploring factors that influence knowledge sharing behavior via weblogs. Computers in Human Behavior, 26(1), 32-41.

Zhang, D. (2013). 旧衣服新旅程[Old clothes, new journeys]. China Entrepreneur, 432, 92-97.

Zhang, J., Mauzerall, D. L., Zhu, T., Liang, S., Ezzati, M., \& Remais, J. V. (2010). Environmental health in China: Progress towards clean air and safe water. The Lancet, 375(9720), 1110-1119.

Publisher's Note Springer Nature remains neutral with regard to jurisdictional claims in published maps and institutional affiliations. 